\title{
Exploring the Technology Transfer Mechanisms by the Multinational Corporations: A Literature Review
}

\author{
Sazali Abdul Wahab \\ National Defense University of Malaysia, Kuala Lumpur 57000, Malaysia \\ Tel: 60-3-9051-3060 E-mail: saw@upnm.edu.my \\ Raduan Che Rose \\ National Defense University of Malaysia, Kuala Lumpur 57000, Malaysia \\ E-mail: raduan@upnm.edu.my \\ Suzana Idayu Wati Osman \\ Felda Global Ventures Holdings, Kuala Lumpur 54000, Malaysia \\ E-mail: suzana.iwo@gmail.com
}

$\begin{array}{lrr}\text { Received: July 28, } 2011 & \text { Accepted: November 10, } 2011 & \text { Published: March 1, } 2012 \\ \text { doi:10.5539/ass.v8n3p142 } & \text { URL: http://dx.doi.org/10.5539/ass.v8n3p142 }\end{array}$

\begin{abstract}
The main objective of this paper is to contribute to the existing technology transfer literature by reviewing and outlining the mechanisms (channels) of technology transfer. This review aims to stimulate and generate dynamic ideas for future researchers i.e. to further identify and understand the technology transfer's channels, the processes prior to the transfer, the parties involved, the type of technologies in the transfer process, and the justification for selecting specific mode of transfer. Since technology transfer literatures cover a wide research area, this paper sets its perimeter by focusing on the transfer mechanisms which involve both intra and inter-firm technology transfer.
\end{abstract}

Keywords: Technology transfer mechanism, Formal and informal market channels, Malaysia

\section{Introduction}

In the context of a developing country, technology is viewed as an important catalyst of corporate success and national economic growth (Millman, 2001). Due to lack of resource capacities such as weak research and development ( $\mathrm{R} \& \mathrm{D}$ ) base, limited investment in $\mathrm{R} \& \mathrm{D}$, production and manufacturing capability, weak infrastructure and technological disadvantage (Lado and Vozikis, 1996; Tepstra and David, 1985) many developing countries depend mainly on foreign direct investments (FDIs) from the multinational corporations (MNCs) as their primary source of technology to enhance the technological capabilities and competitiveness of local industries (Lee and Tan, 2006). This is mainly because MNCs own, produce and control the bulk of world technology in which they undertake nearly $80 \%$ of all private R\&D expenditures worldwide (Dunning, 1993). The technologies which are transferred by MNCs benefit the host country in terms of achieving long term economic growth (Marton, 1986; Blomstrom, 1990), providing a higher potential of innovation performance/capabilities (Guan, Mok, Yam and Pun, 2006; Kotabe, Dunlap-Hinkler, Parente and Mishra, 2007), increasing technological capabilities (Kumar, Kumar and Persaud, 1999; Madanmohan, Kumar and Kumar, 2004), enhancing the organizations' competitive advantage (Liao and Hu, 2007; Rodriguez and Rodriguez, 2005), enhancing the organizational learning effectiveness (Inkpen, 2000; Inkpen and Dinur, 1998), providing a positive effect on productivity (Caves, 1974; Xu, 2000; Liu and Wang, 2003), and increasing the technological development of local industry (Markusen and Venables, 1999). Other research studies have proposed technology transfer as one mechanism by which developing countries can break the vicious cycle of economic underdevelopment (Lado and Vozikis, 1996; Samli, 1985). From the technology transfer initiatives, the host-country will also benefit in terms of improving quality of life, achieving technology progression through 
research and development, and increasing tax revenue. For the MNCs, the benefits are in terms of more equitable trade agreements, global expansion and increase in market share (Madu, 1989).

As the main source of technology and knowledge, the multinational corporations (MNCs) provide their technologies to the host countries through various channels. In order to achieve their economic objectives, MNCs must carefully consider the appropriate mechanism of transfer in their strategic decision especially the type of entry modes. Among the main and effective technology transfer channels are exporting, foreign direct investment (FDI), licensing and joint venture. The choice of technology transfer channels depends on the nature of the technology such as age, complexity, characteristic of the host country, education level of the workforce, labor skills, technology transfer requirements and local competition (Sinani and Meyer, 2004). Sazali and Raduan (2011) suggest that a strong understanding on the theories underlying technology transfer is necessary to enable the interested parties (such as private sectors, government departments, academics, researchers and students) to relate with the practical and empirical aspects of various technology transfer models, mechanism, issues and challenges.

Past studies have found that MNCs tend to transfer 1) young and new technologies to their subsidiaries and affiliates in the developed countries, 2) older technologies to subsidiaries and affiliates in the developing countries, and 3) technologies transferred through licensing and joint ventures is older than technology transferred to their affiliates (Mansfield and Romeo,1980). From the knowledge-based perspective, Kogut and Zander (1993) establish that the mode of technology transfer depends on the technology's attributes such as tacitness, codifiability and teachability. They suggest that the propensity of MNCs to transfer technology to a wholly-owned subsidiary is high when the technology is tacit or complex and the more codifiable the technology, the more likely it to be transferred through licensing. Consistent with Mansfield and Romeo (1980), Cave (1999) also argues that FDI is the appropriate mode transferring technology to subsidiaries when the technologies are new, young and complex.

This paper argues that a strong understanding on how technologies are transferred through various mechanisms in different settings is important to help us understand: 1) the rationale and justifications on why certain methods of transfer are chosen by the technology supplier (MNCs) and 2) the relevant underlying theories/perspectives of technology transfer that govern the transfer process and mode of transfer (Sazali and Raduan, 2011). This paper categorizes technology transfer channels into two main groups. The first group is the formal market channels: direct export of technology (exporting), foreign direct investment (FDI), licensing, and international joint venture. The second group of technology transfer channels involves the informal or non-market channels: imitation, movement of personnel, data in patents and test data, and temporary migration (Maskus, 2003).

\section{Technology transfer through formal market channel.}

The primary focus of this section is provide better understanding on how technology and knowledge are being transferred by MNCs to local firms in the host countries through formal market channels such as exporting capital goods (exporting), foreign direct investment (wholly owned subsidiaries), licensing and joint ventures. These transfer channels are regarded as the most efficient transfer channels undertaken by MNCs when transferring their technology to the host countries; where the technology flows through market-mediated mechanism with some form of formal transaction underlies the technology movement. On the other hand, the non-market channels refer to technology transfer mechanisms that do not involve a formal market transaction (Maskus, 2003).

\subsection{Direct Exporting}

Direct exporting products/goods is considered as 'an externalized mechanism' and part of the inter-firm technology transfer. This is so when the technology-supplier (MNCs) transfers technology that embodies in product or capital goods and equipments to the recipient out of their organizational boundary. Maskus (2003) argues that exporting goods and services creates potential for transferring technological information to the technology-recipient because they can easily absorb, adapt and improve the acquired technology in the capital goods and equipments if they have the capabilities to undertake efficient learning. Direct exporting offers the technology-suppliers a relatively low-cost and low-risk entry into foreign markets and is typically the initial phase of internationalization ( $\mathrm{Lu}$ and Beamish, 2001). When compared to other modes of technology transfer for example licensing, joint venture or wholly owned subsidiary, exporting involves production in the home country where the technology-supplier do not retain any significant controls over the use, technology and sales decision, or the re-transfer of the technology ( Lall,1993). Due to limited resources, exporting offers MNCs less control over the marketing and distribution of goods in the host country (Naidu and Prasad, 1994; Leonidou and Katsikeas, 1996). 
Ibrahim and Mcguire (2001) suggest that since exporting does not require large investment and involves very little financial risk, it offers less opportunity for MNCs to learn about the foreign market. Exporting of goods and services is suitable when technology transfer requires little innovation or adaptation and is appropriate if MNCs find it impractical to impose restrictions on the uses of the technology (Ibrahim and Mcguire, 2001). Other than having less control over the technology and lack of knowledge about the host country, Niosi and Rivard (1990) argue that exporting goods could be difficult or impossible due to the protectionist policies in the host country that increase the possibility of losing the advantage of distance, lower labor and resource cost in the host country (Niosi and Rivard, 1990). To overcome these obstacles MNCs would prefer to invest in the host country, control their technology, marketing and organization assets through a subsidiary (Nisosi and Rivard, 1990).

Taylor et al. (2000) argue, from the bargaining power perspective, exporting does not involve bargaining with the host country when the goods or products are produced in the home country. Ibrahim and Mcguire (2001) assert that through exporting MNCs may sell the technology to the recipient in the host country or use the expertise of the export management firm and as a result if MNCs find that the opportunity is large enough in the host country to transfer technology they may embark on a direct approach by setting up sales office in the host country to sell the technology (Allen, 1999). In the Indonesian context, exporting capital goods to the host country indirectly promotes technology transfer through trainings provided by the technology-suppliers' experts to the local firms especially on how to operate, maintain, and repair the imported machinery (Thee, 2005). Previous studies have confirmed that the foreign research and development (R\&D) embodied in the imported capital goods has a significant positive impact on total factor productivity (TPF) of the importing countries (Coe et al., 1997). Schiff et al. (2002) find that the impact on TPF is greater if 1) the importing countries' policies are more open, 2) there is availability of highly skilled labors, and 3) increase in trades with the developed countries.

\subsection{Foreign Direct Investment}

Another market channel of technology transfer is through foreign direct investment (FDI) by MNCs. This type of technology transfer is considered as 'the internalized mechanism' or intra-firm technology transfers from MNCs to their subsidiaries or affiliates in the host country. Technology transfer through FDI provides access to the whole range of technological, organizational, and knowledge assets as well as to marketing expertise and brand names within MNCs (Ivarsson and Alvstam, 2005). Niosi and Rivard (1990) argue that MNCs prefer to internalize the market of their assets by forming subsidiaries to control their technology and the use of their productive facilities. Previous research suggests that transferring technology through FDI by MNCs to the wholly owned subsidiaries is appropriate 1) when the technology is young and new, 2) when the technology is complex to learn and diffuse, and 3) when it requires skills and competencies that are not available in the host countries (Lado and Vozikis, 1996; Zander and Kogut, 1995). Harris and Ravenscraft (1991) argue that firms from high technology industries such as MNCs frequently enter foreign market to cover their cost in the R\&D investment, prevent product obsolescence, and gain market share. Through direct investment, MNCs transfer and share their proprietary technologies, skills, and knowledge with their local subsidiaries or affiliates with the primary objective of gaining profit or amortizing the cost of R\&D over a large quantity of products being sold (Tihanyi and Roath, 2002). MNCs opt for FDI as a technology transfer mechanism when the transaction cost is high especially where the technology is not standardized, difficult to codify and transmitted through design and drawings, or when technology's content is highly tacit (Siddharthan, 1992).

In situations where the transaction cost is high MNCs would prefer to have equity participation or wholly owned subsidiary in order to have control over their operation in the host countries (Siddharthan, 1992). Furthermore, Niosi and Rivard (1990) argue that MNCs, when transferring technology to subsidiary or affiliates in the host country, are expected to face legal barriers and economic obstacles. Among the legal barriers are policies prohibiting wholly owned subsidiary or even minority affiliates, and the host government's policy to implement mandatory technology transfer. Other than these barriers the economic obstacles do exist when there is strong internal competition by established firms, high fixed costs of forming a subsidiary or management shortage for the exporter (Niosi and Rivard, 1990). Technology transfer through FDI has not only extended technology to the MNCs' subsidiaries and affiliates through internalized transfer of technology and knowledge; where MNCs can retain and control the technology internally, but it also capable of creating positive externalities in the form of technology spillover. Spillovers occur when MNCs as the technology owner are no longer able to retain technology internally or internalize the full value of the benefits associated with the technology (Lorentzen et al., 2003). Blomstrom and Kokko (1998) suggest that technology spillover are evident when local firms begin to imitate technology from the MNCs affiliate, or the local firms become more efficient and innovative due to increase in competition from the entry of foreign firms into their market. 
According to Sinani and Meyer (2004) technology spillovers could occur through demonstration effects; when the local firms have the opportunity to learn by observing the MNCs operate their superior technology (Findly, 1978). Exposure to the MNCs' superior technology may force the local firms to improve their own production methods. By noticing and understanding new product innovation or new form of organization adapted to local conditions, the local firms will attempt to imitate the innovation or managerial knowledge. Blomstrom and Kokko (1996) found that frequent interactions with local firms will lead to diffuse of information being diffused, reduce uncertainty and eventually increase the level of imitation. Secondly, technology spillovers may also occur through labor turnover; when employees previously trained or employed by the MNCs transfer important technology or information to local firms or when they start their own firms/business (Sinani and Meyer, 2004; Wang, 1990). Thirdly, technology spillovers may occur through backward and forward linkages; when the MNCs transfer technology to the local supplier of the intermediate goods or buyers of their own products to economize on transportation costs or to accommodate local requirements in cases of subcontracting or original-equipment-manufacturing (Sinani and Meyer, 2004).

\subsection{Licensing}

Another form of externalized technology transfer is through licensing agreements; which may be done either within a joint venture or between unrelated firms at arms-length across countries (Maskus, 2003). Licensing is an act of granting permissions or rights to make, use and/or sell a certain product, design or process, or to perform certain actions by the licensor to the licensee (Anon, 1995). In general there are two types of technology licensing package: 1) the technology licensing agreement which covers the conveyance of patent, trademark and other rights for example right to make, distribute, use, and sell the product, design or process; and 2) the technical licensing agreement which contains the provisions of technical and managerial assistance to a licensee (Contractor, 1980). According to Maskus (2003) license contracts cover a variety of transactions which include technical assistance, codified knowledge and know-how, establishment of turnkey operations and intellectual property rights. In exchange of the technology, the licensee pays the licensor a fixed licensing fee, a franchise fee, a royalty schedule, or a share of profits.

Past studies have identified various motives why MNCs and local firms engage in licensing agreements. Millman (2001) identifies motives for having licensing agreement such as 1) to fill gaps in the product range; 2) to enable a relatively small company to quickly commercialize a product in a large market; 3 ) to diversify into a new business area; 4) to seek a return on part or fully developed technology which has good commercial potential but does not fit into the licensor's business strategy; 5) to take advantage of a major breakthrough in process efficiency and product quality, and 6) to separate marketing from manufacturing. Siddharthan (1992) argues that the MNCs would prefer to transfer technology through licensing or arms-length sale in situation where brand names are not involved, and when technologies could be transferred through sale of design and drawings. Maskus (2003) distinguishes between intra-firm licensing (non-market mediated licensing) and inter-firm licensing (market-mediated licensing). For intra-firm licensing, the MNCs retain significant proprietary control over the intellectual property, and know-how of the product, design or process; whereas for inter-firm licensing (market-mediated licensing) the MNCs must provide the licensee the access to these assets. In this context patents, trade secrets, copyrights and trademarks act as direct means of information transfer.

Since licensing provides a relatively low risk and stable income to MNCs, this channel would be the most preferred strategy for the MNCs that do not have sufficient management and financial resources to undertake FDI in several countries (Dollinger, 1995). Zander and Kogut (1995) suggest that licensing is more appropriate for less complex technologies and technologies that can be easily diffused and learned by the affiliates or local subsidiaries. When compared to joint ventures and equity partnerships, licensing provides MNCs a quick and easy entry to the foreign market (Harringan, 1985; Hagedoorn and Narula, 1996). Ibrahim and Mcguire (2001) argue that licensing does not require MNCs to have extensive knowledge about the host countries' market and is appropriate when technology only requires limited adaptation and innovation.

Licensing agreement which is made through negotiation between the licensor (MNCs) and licensee (unrelated firms) may promote a voluntary technology transfer. Whereas in situations where 'compulsory technology transfers' exist (especially where the host governments' policies demand MNCs to surrender the rights to the local firm) the licensing agreements do not really contribute to the transfer of relevant know-how which is not embodied in patent or trademark rights (Maskus, 2003). MNCs' decision to transfer technology through licensing is largely depend on the market size, policy certainty, host country transparency and the licensor's confidence that the proprietary technologies are not diffused into the host country through imitation or employees' turnover (Hoekman et al. (2005). From the Indonesia experience, Thee (2005) found that the MNCs 
are not in favor of entering technical licensing agreements with local firms because of the country's weak protection of intellectual property rights.

\subsection{International Joint Ventures}

Other than direct exporting of goods, foreign direct investments and licensing, another form of formal and externalized mechanism of technology transfer by MNCs is by forming joint ventures with local firms. Joint ventures are viewed as a collaborative effort by MNCs and local partners particularly in sharing their individual resources skills and expertise (Ibrahim and Mcguire, 2001). Joint ventures allow the MNCs and local partners to share different skills and knowledge bases to create unique learning opportunities (Inkpen, 1998). MNCs tend to embark on joint venture and strategic alliance for various reasons such as to achieve economic goals by reducing investment risks, to share technological know-how and management expertise, to improve operational efficiency and to strengthen global competitiveness (Caves, 1996; Harrigan, 1988; Perlmutter, 1986). Harrigan (1984) states that joint ventures provide both MNCs and local partners opportunities to facilitate the transfer of knowledge, particularly for knowledge that are not easily be transferred without the setting up of a joint venture (for example institutional and cultural knowledge). Other studies argue that joint venture is appropriate when technology can be easily learned and diffused to local partners who possess sufficient skills and expertise to handle the imported technology (Lado and Vozikis, 1996; Zander and Kogut, 1995). Through joint ventures, the MNCs and local firms are expected to contribute and share knowledge and expertise between them. Previous studies have acknowledge that local firms could contribute their knowledge and information in terms of local economic condition, political stability, cultural differences, business customs, customers' preference and taste, information on local work force, distribution channels, infrastructure and information on raw material supplies in the host countries (Shrader, 2001). In return, MNCs may contribute their technological know-how, managerial expertise and other intangible assets. The MNCs would prefer joint venture with local firms if there are inherent advantages such as ability to create niche in the foreign market early and opportunity to enjoy favorable treatment in terms of low taxes/duties and easy transfer of profits back to home countries. On the other hand, the local firms in the developing countries would prefer joint venture as it provides the local firms the opportunities to participate in the management and control of the venture, to gain the technological and managerial skills, and to share the venture's profit (Ibrahim and Mcguire, 2001).

Previous studies have confirmed that transferring knowledge and technology through strategic alliance and joint ventures will depend on various joint venture characteristics factors which include organizational distance (Simonin, 1999a, 1999b), knowledge connection (Inkpen, 2000), organizational structure (Inkpen,1997), ownership type (Kogut, 1998; Mowery et al., 1996), relationship openness (Hamel, 1991; Inkpen, 2000), attachment between partners (Inkpen and Beamish, 1997), empathy (Buckley et al., 2002) and relationship quality (Szulanski, 1996). Other than joint venture characteristic factors, the strategic alliance' partners factors such as partners protectiveness (Simonin, 1999b, 2004; Szulanski, 1996), motivation (Szulanski, 1996), control (Lyles et al., 2003), prior experience (Subramaniam and Venkatraman, 2001), source transfer capacity (Martin and Salomon, 2003), absorptive capacity (Cohen and Lavinthal,1990; Lane et al., 2001), recipient experience (Simonin, 1999, Zander and Kogut,1995), learning intent (Beamish and Berdrow, 2003; Hamel, 1991) and rigidity of managerial belief (Inkpen and Crossan, 1995) have been identified by the researchers to have contributed to the success of technology transfer. Past studies have acknowledged that joint venture has been well accepted as an effective channel of technology transfer. Moeini and Zawdie (1998) find that joint ventures are more successful than other forms of channels in bridging the knowledge and skills gap in the learning-innovation link.

\section{Technology transfer through non-market channels}

Although this study stresses more on transferring technology through formal market channels, the understanding on how technology and knowledge are transferred through non-market channel is also useful because of the interface between formal market channel and non-market channel and various underlying theories (Maskus, 2003).

\subsection{Imitation}

As a formal market mechanism used by the MNCs to transfer technology to their subsidiaries and affiliates, FDI promotes/encourages technology spillovers through demonstration effects. Demonstration effect occurs when local firms have the capability to learn and subsequently imitate the MNCs' new product innovation or new form of organizational processes obtained by observing how the MNCs operate their advance technology. Blomstrom and Kokko (1996) argue that imitation in formal market channel occurs through interactions between the firms and the existing technology users: which creates information diffusion and reduce uncertainty of information. In 
the context of non-market channel of technology transfer, imitation materializes when a rival firm imitates the technology or design or secret of another firm's formula or product. A rival firm may achieve imitation through product inspection, reverse engineering, 'decompilation' of software or even through trial and error innovations (Maskus, 2003). Maskus (2003) further argues that imitation differs from the other formal market channel because it bears no compensation to the technology owner and/or supplier in the formal market.

\subsection{Movement of personnel}

Technology and knowledge may also be transferred through the movement of people (employees). In the market channel, the relationships between exporting, FDI, licensing, joint venture and cross border movement of personnel are interdependent (Maskus, 2003).Technology transfer through movement of personnel is implemented through shifting of expatriate engineers and managers, short-term visit of experts from MNCs' parent company to its subsidiaries and affiliates or by sending local subsidiaries employees to foreign supplier or parent company (Banik and Subbayamma, 2000). Technology transfer through the movement of staff occurs, particularly during the implementation of FDI, licensing or joint venture, when personnel and experts from MNCs' parent company are needed to assist its local subsidiaries and affiliates, local firms, local licensor or joint venture company on the production processes, operation or managerial processes by transferring uncodified technology, know-how, unformalized personnel' experience and expertise. This mechanism of transfer is important because many technologies cannot be effectively or affordably transferred without the complementary services and know-how of MNCs' personnel (Maskus, 2003). In the context of non-market channels, the movement of local MNCs' personnel could contribute to the spillover's effect of technology; when the former local MNCs employee bringing with them their technological information, know-how and expertise to local rival firms or by taking it to their new entrepreneurial businesses (Sinani and Meyer, 2004).

\subsection{Data in patent application and test data}

Another non-market channel, which allows technology to be transferred without involving the market, is through the information obtained by the rival firms from the available data in patent applications that were registered in a country or abroad. Information or data in the patent application may enable the rival firm to have free and direct access to technology, opportunity to inspect and understand the complex technologies involved and consequently develop competing processes or products that do not infringe the claims of the patent's owner (Maskus, 2003). Maskus (2003) argues that a confidential test data; which was provided by the patent's owner to the government agencies, indirectly allows the local rival firms to have access to the data upon the expiry of period of exclusivity awarded to the patent's owner.

\subsection{Communication media}

Other than the above non-market channels, past studies have identified various communication media that have facilitated technology transfer indirectly. Banik and Subbayamma (2000) suggest that technology may also be transferred through communication media which includes written document, telephones conversations, faxes, e-mails, memos, reports, newsletters and journals. Rogers et al. (2001), in their study on technology transfer from R\&D laboratories and research universities in metropolitan regions in U.S, identified that technology transfer occurs through various channels of communication including spin-offs i.e. companies which are formed by former employee of a parent organization with a core technology that is transferred from that parent organization including the license, publication, meetings and cooperative R\&D agreements (CRADAs).

\subsection{Temporary migration}

Temporary migration refers to technologies that are being transferred through temporary migration or movement of students, scientists, managerial and technical personnel to universities, laboratories, and conferences located in the developed countries. Technology transfer occurs through in-depth training and research in science and engineering (Maskus, 2003).

\section{Conclusion}

Based on the discussion on technology transfer channels; which are gathered from various literatures, to increase global competitiveness, technological capabilities, and potential for local innovation, organizations in the developing countries are striving hard to collaborate, learn and internalize their foreign partners' technology and knowledge (Sazali and Raduan, 2011). This review could help to stimulate and generate ideas for future researchers to further identify, conceptualize and understand the technology transfer channels as implemented by the MNCs when dealing with their counter part from developing countries. As indicated earlier, the mechanisms used are closely related to the type of technology (tacit, explicit or complex), age of technology, level of protectiveness, contextual factors and learning capabilities of the technology recipients. 


\section{References}

Allen, T. J. \& Cooney, S. (1971). The International Technological Gatekeeper. Technology Review, 73 (5): p. $2-9$.

Anon. (1995). The Basics of Licensing, Licensing Executive Society of USA and Canada, Alexandria, VA.

Banik, Arindam \& G Subbaymma. (2000). Technology Transfer in Asia: Case of Latecomer Firms, paper presented in a conference in Globalization and the Uniqueness of Asia, Euro-Asia Management Studies Association, INSEAD's Campus in Asia, Singapore, November 23-25, 2000.

Beamish, P. W. \& Berdrow, I. (2003). Learning from International Joint Ventures - the Unintended Outcome, Long Range Planning, 36, p. 285-303. http://dx.doi.org/10.1016/S0024-6301(03)00047-5

Blomstrom, M. \& Kokko, A. (1998). Multinational Corporations and Spillovers. Journal of Economic Surveys, 12 (3), p. 247-77. http://dx.doi.org/10.1111/1467-6419.00056

Buckley, J. Peter, Jeremy Clegg \& Chengqi Wang. (2002). The impact of inward FDI on the performance of China's manufacturing firms. Journal of International Business Studies, 33(4), pp. $637-655$. http://dx.doi.org/10.1057/palgrave.jibs.8491037

Caves, R. E. (1974). Multinational Firms, Competition and Productivity in Host-Country Markets. Economica, 41, p. 176-193. http://dx.doi.org/10.2307/2553765

Caves, R. E. (1996). Multinational Enterprise and Economic Analysis (Second Edition). Cambridge: Cambridge University Press.

Coe, D.T., Helpman, E. \& Hoffmaister, A.W. (1997). North-south R\&D spillovers. The Economic Journal, 107, 134-149. http://dx.doi.org/10.1111/1468-0297.00146

Cohen, W. M. \& Levinthal, D. A. (1990). Absorptive Capacity: A New Perspective on Learning and Innovation. Administrative Science Quarterly, 35 (1), p. 128-52. http://dx.doi.org/10.2307/2393553

Contractor, F. J. (1980). The profitability of technology licensing by U.S. multinationals. Journal of International Business Studies, 11, 40-63. http://dx.doi.org/10.1057/palgrave.jibs.8490604

Dollinger, M. J. (1995). Entrepreneurship: Strategies and Resources. Irwin, Boston.

Dunning, J. H. (1993). Multinational Enterprise and the Global Economy. Reading, MA: Addison-Wesley.

Findlay. (1978). Relative backwardness, direct foreign investment and the transfer of technology: A simple dynamic model. Quarterly Journal of Economics, 92, 1-16.

Guan, J. C., Mok, C. K., Yam, C. M. \& Pun, K. F. (2006). Technology Transfer and Innovation Performance: Evidence from Chinese Firms. Technological Forecasting and Social Change, 73, p. 666-678. http://dx.doi.org/10.1016/j.techfore.2005.05.009

Hamel G. (1991). Competition for Determinant and Interpartner Learning within International Strategic Alliances. Strategic Management Journal, 12, p. 83-103. http://dx.doi.org/10.1002/smj.4250120908

Harrigan, K. R. (1988a). Joint Ventures and Competitive Strategy. Strategic Management Journal, 9, p. $141-158$. http://dx.doi.org/10.1002/smj.4250090205

Harris, and Ravenscraft, R.S. Harris \& D. Ravenscraft. (1991). The role of acquisitions in foreign direct investment: Evidence from the U.S. stock market. Journal of Finance, 46, pp. 825-844.

Hoekman, B., Maskus, K. \& Saggi, K. (2005). Transfer of technology to developing countries: unilateral and multilateral policy options. World Development, $33(10), \quad$ pp. 1587-1602. http://dx.doi.org/10.1016/j.worlddev.2005.05.005

Ibrahim, A. B. \& McGuire, J. (2001). Technology Transfer Stratégies for International Entrepreneurs. International Management, 6 (1), p. 75-83.

Inkpen, A. C. \& Beamish, P. W. (1997). Knowledge Bargaining Power and the Instability of International Joint Ventures. Academy of Management Review, 22 (1), p. 177-199.

Inkpen, A. C. \& Crossan, M. M. (1995). Believing is Seeing: Joint Ventures and Organizational Learning. Journal of Management Studies, 32 (5), p. 596-618. http://dx.doi.org/10.1111/j.1467-6486.1995.tb00790.x

Inkpen, A. C. \& Dinur, A. (1998). Knowledge Management Processes and International Joint Ventures. Organization Science, 9 (4), p. 454-468. http://dx.doi.org/10.1287/orsc.9.4.454

Inkpen, A. C. (2000). Learning through Joint Ventures: A Framework of Knowledge Acquisition. Journal of Management Studies, 37 (7), p. 1019-1043. http://dx.doi.org/10.1111/1467-6486.00215

Ivarsson, Inge \& Claes Goran Alvstam. (2005). Technology Transfer from TNCs to Local Suppliers in Developing Countries: A Study of AB Volvo's Truck and Bus Plans in Brazil, China, India and Mexico. World Development, Vol. 33, No. 8, p. 1325-1344. http://dx.doi.org/10.1016/j.worlddev.2005.04.011 
Kogut, B. \& Zander, U. (1993). Knowledge of the Firm and the Evolutionary Theory of the Multinational Corporation. Journal of International Business Studies, 24 (4), p. 625-646. http://dx.doi.org/10.1057/palgrave.jibs.8490248

Kogut, B. (1988). Joint Ventures: Theoretical and Empirical Perspectives. Strategic Management Journal, 9 (4), p. 319-32. http://dx.doi.org/10.1002/smj.4250090403

Kotabe, M., Dunlap-Hinkler, D., Parente, R. \& Mishra, H. (2007). Determinants of Cross-National Knowledge Transfer and Its Effect on Firm Innovation. Journal of International Business Studies, 38, p. 259-282. http://dx.doi.org/10.1057/palgrave.jibs.8400261

Kumar, V., Kumar, U. \& Persaud, A. (1999). Building Technological Capability through Importing Technology: The Case of Indonesian Manufacturing Industry. Journal of Technology Transfer, 24, p. 81-96. http://dx.doi.org/10.1023/A:1007728921126

Lado, A. \& Vozikis, G. (1996). Transfer of Technology to Promote Entrepreneurship in Developing Countries: An Integration and Proposed Framework. Entrepreneurship Theory and Practice, Winter, p. 55-72.

Lall, S. (1982). Developing Countries as Exporters of Technology: A First Look at the Indian Experience. Macmillan, London.

Lane, P. J., Salk, J. E. \& Lyles, M. A. (2001). Absorptive Capacity, Learning, and Performance in International Joint Ventures. Strategic Management Journal, 22 (12), p. 1139-61. http://dx.doi.org/10.1002/smj.206

Lee, H. H. \& Tan, H. B (2006). Technology Transfer, FDI and Growth in the ASEAN Region. Journal of the Asia Pacific Economy, 11 (4), p. 394-410. http://dx.doi.org/10.1080/13547860600923593

Liao, S. H. \& Hu, T. C. (2007). Knowledge Transfer and Competitive Advantage on Environmental Uncertainty: An Empirical Study of the Taiwan's industry. Technovation, 27, p. 402-411. http://dx.doi.org/10.1016/j.technovation.2007.02.005

Liu, X. \& Wang, C. (2003). Does Foreign Direct Investment Facilitate Technological Progress? Evidence from Chinese Industries. Research Policy, 32, p. 954-953. http://dx.doi.org/10.1016/S0048-7333(02)00094-X

Lorentzen, J., Møllgaard, P. \& Rojec, M. (2003). Host-country absorption of technology: Evidence from automotive supply networks in Eastern Europe. Industry and Innovation, 10(4): 415-32. http://dx.doi.org/10.1080/1366271032000163658

Lu, J. \& Beamish, P. (2001). The internationalization and performance of SMEs. Strategic Management Journal, Vol. 22, No. 6/7, pp. 56586.

Lyles, M. A., von Krogh, G. \& Aadne, J. H. (2003). Knowledge Acquisition and Knowledge Enablers in International Joint Ventures and their Foreign Parents. Management International Review, 3, Special Issue, p. 111-129.

Madanmohan, T. R., Kumar, U. \& Kumar, V. (2004). Import-led Technological Capability: A Comparative Analysis of Indian and Indonesian Manufacturing Firms. Technovation, p. 979-993. http://dx.doi.org/10.1016/S0166-4972(03)00030-0

Madu, C. N. (1989). Transferring Technology to Developing Countries - Critical Factors for Success. Long Range Planning, 22 (4), p. 115-124. http://dx.doi.org/10.1016/0024-6301(89)90089-7

Mansfield, E. \& Romeo, A. (1980). Technology transfer to overseas subsidiaries by US-based firms. Quarterly Journal of Economics, 95, pp. 737-750. http://dx.doi.org/10.2307/1885489

Mansfield, E. (1975). International Technology Transfer: Forms, Resource Requirement and Policies. American Economic Review, 65, 372-376.

Markusen, J. R. \& Venables, A. J. (1999). Foreign Direct Investment as a Catalyst for Industrial Development. European Economic Review, 43, p.335-356. http://dx.doi.org/10.1016/S0014-2921(98)00048-8

Martin, X. Y. F. \& Salomon, R. (2003). Knowledge Transfer Capacity and its Implications for the Theory of the Multinational Corporation. Journal of International Business Studies, 34 (4), p. 356-373. http://dx.doi.org/10.1057/palgrave.jibs.8400037

Marton, K. (1986). Multinationals, Technology and Industrialization. Hearth. MA: Lexington

Maskus, K. E. (2003). Encouraging International Technology Transfer. UNCTAD/ICTSD Capacity Building Project. On Intellectual Property Rights and Sustainable Development.

Millman, A. F. (2001). Technology Transfer in the International Market. European Journal of Marketing, 17 (1), p. 26-47. http://dx.doi.org/10.1108/EUM0000000004806

Moeini, E. \& Zawdie, G. (1998). Import Substitution, Technological Learning and Innovation in Strategic Industries in Iran: A Survey of Evidence. Science, Technology and Development, 16 (1), p. 17-43. 
Mowery, D. C., Oxley J. E. \& Silverman B. S. (1996). Strategic Alliances and Interfirm Knowledge Transfer. Strategic Management Journal, 17, p. 77-91.

Naidu, G.M. \& Prasad, V.K. (1994). Predictors of export strategy and performance of small and medium-sized firms. Journal of Business Research, 31, pp. 107-115. http://dx.doi.org/10.1016/0148-2963(94)90075-2

Niosi, J. \& Rivard, J. (1990). Canadian Technology Transfer to Developing Countries by Small and Medium Enterprises. World Development, (November), Vol. 18, No. 11, p.1529-1542.

Perlmutter, H. W. \& Heenan, D. A. (1986). Cooperate to Compete Globally. Harvard Business Review, 64, March-April, p. 136-142.

Rodriguez, J. L. \& Rodriguez, R. M. G. (2005). Technology and Export Behavior: A Resource-Based View Approach. International Business Review, 14, p. 539-557. http://dx.doi.org/10.1016/j.ibusrev.2005.07.002

Rogers, E. M., Takegami, S. \& Yin, J. (2001). Lesson Learned about Technology Transfer. Technovation, p. 253-261. http://dx.doi.org/10.1016/S0166-4972(00)00039-0

Samli, A. (1985). Technology Transfer: Geographic, Economics, Cultural, and Technical Dimensions. Westport, CT, Quorum Books.

Sazali A. W \& Raduan C. R. (2011). The Handbook of Inter Firm Technology Transfer - An Integrated Knowledge-Based View and Organizational Learning Perspective. LAP LAMBERT Academic Publishing GmbH \& Co KG: Germany, ISBN: 978-3-8454-1366-2.

Sazali, A.W. \& Raduan, C.R. (2011). The Inter Firm Technology Transfer in Malaysia - A Holistic Approach. VDM Verlag Publishing, Saarbrucken, Germany. ISBN: 978-3-639-36453-8.

Schiff, M., Y. Wang \& M. Olarreaga. (2000). North-South and South-South Trade-Related Technology Diffusion: An Industry-Level Analysis. Mimeo, DECRGIT, World Bank.

Shrader, R. C. (2001). Collaboration and Performance in Foreign Markets: The Case of Young High-Technology Manufacturing Firms. Academy of Management Journal, 44 (1) (2001), p. 45-60. http://dx.doi.org/10.2307/3069336

Siddharthan, N. S. (1992). Transaction costs, technology transfer and in-house R\&D: A study of the Indian private corporate sector. Journal of Economic Behaviour and Organization, 18, pp.265-271. http://dx.doi.org/10.1016/0167-2681(92)90031-6

Simonin, B. L. (1999a). Ambiguity and the Process of Knowledge Transfer in Strategic Alliances. Strategic Management Journal, $20 \quad$ (7), $\quad$ p. $\quad$ 595-623. http://dx.doi.org/10.1002/(SICI)1097-0266(199907)20:7<595::AID-SMJ47>3.0.CO;2-5

Sinani, E. \& Meyer, K. E. (2004). Spillovers of Technology Transfer from FDI: The Case of Estonia. Journal of Comparative Economics, 32, p. 445-466. http://dx.doi.org/10.1016/j.jce.2004.03.002

Subramaniam, M. \& Venkatraman, N. (2001). Determinants of Transnational New Product Development Capability: Testing the Influence of Transferring and Deploying Tacit Overseas Knowledge. Strategic Management Journal, 22 (4), p. 359-378. http://dx.doi.org/10.1002/smj.163

Szulanski, G. (1996). Exploring Internal Stickiness: Impediments to the Transfer of Best Practice within the Firm. Strategic Management Journal, 17 (Winter Special Issue), p. 27-43.

Taylor, M. Z. (1995). Dominance Through Technology: Is Japan Creating a Yen Block in Southeast Asia? Foreign Affairs, 74 (6), p.14-20. http://dx.doi.org/10.2307/20047376

Tepstra, V. \& David, K. (1985). The Cultural Environment of International Business. Cincinnati,, OH: Southwestern Publishing Co.

Thee, K. W. (2005). The Major Channels of International Technology Transfer to Indonesia: An Assessment. Journal of the Asia-Pacific Economy, Vol. 10, No. 2, pp. 214-36. http://dx.doi.org/10.1080/13547860500071493

Tihanyi, L. \& Roath, A. S. (2002). Technology Transfer and Institutional Development in Central and Eastern Europe. Journal of World Business, 37, p. 188-198. http://dx.doi.org/10.1016/S1090-9516(02)00077-9

Wang, J. Y. (1990). Growth, Technology Transfer, and the Long Run Theory of International Capital Movements. Journal of International Economics, $29 \quad$ (3-4), p. 255-71. http://dx.doi.org/10.1016/0022-1996(90)90033-I

Xu, B. (2000). Multinational Enterprises, Technology Diffusion, and Host Country Productivity Growth. Journal of Development Economics, 62, p. 477-493. http://dx.doi.org/10.1016/S0304-3878(00)00093-6

Zander, U. \& Kogut, B. (1995). Knowledge and the Speed of the Transfer and Imitation of Organizational Capabilities: An Empirical Test. Organization Science, 6 (1), p.76-92. http://dx.doi.org/10.1287/orsc.6.1.76 